This item was submitted to Loughborough's Research Repository by the author.

Items in Figshare are protected by copyright, with all rights reserved, unless otherwise indicated.

\title{
The role of Islamic social finance in societal welfare: a case study of selected IFBOs in southwest Nigeria
}

\author{
PLEASE CITE THE PUBLISHED VERSION
}

https://doi.org/10.1108/IMEFM-06-2019-0229

\section{PUBLISHER}

Emerald Publishing Limited

\section{VERSION}

AM (Accepted Manuscript)

\section{PUBLISHER STATEMENT}

This paper was accepted for publication in the journal International Journal of Islamic and Middle Eastern Finance and Management and the definitive published version is available at https://doi.org/10.1108/IMEFM06-2019-0229. This author accepted manuscript is deposited under a Creative Commons Attribution Noncommercial 4.0 International (CC BY-NC) licence. This means that anyone may distribute, adapt, and build upon the work for non-commercial purposes, subject to full attribution. If you wish to use this manuscript for commercial purposes, please contact permissions@emerald.com.

\section{LICENCE}

CC BY-NC 4.0

\section{REPOSITORY RECORD}

Shuaib, Abdullah A, and M Sohail. 2021. "The Role of Islamic Social Finance in Societal Welfare: A Case Study of Selected Ifbos in Southwest Nigeria". Loughborough University. https://hdl.handle.net/2134/16622569.v1. 


\section{emerald International Journal of Islamic and Middle Eastern F PUBLISHING

The Role of Islamic Social Finance in Societal Welfare: A Case Study of Selected IFBOs in Southwest Nigeria

\begin{tabular}{|r|l|}
\hline Journal: & $\begin{array}{l}\text { International Journal of Islamic and Middle Eastern Finance and } \\
\text { Management }\end{array}$ \\
\hline Manuscript ID & IMEFM-06-2019-0229.R2 \\
\hline Manuscript Type: & Research Paper \\
\hline Keywords: & $\begin{array}{l}\text { Faith-based organizations, Social services, sadaqah, Zakah, Waqf, } \\
\text { Islamic social finance }\end{array}$ \\
\hline \multicolumn{2}{|r}{} \\
\hline
\end{tabular}

\section{SCHOLARONE Manuscripts}




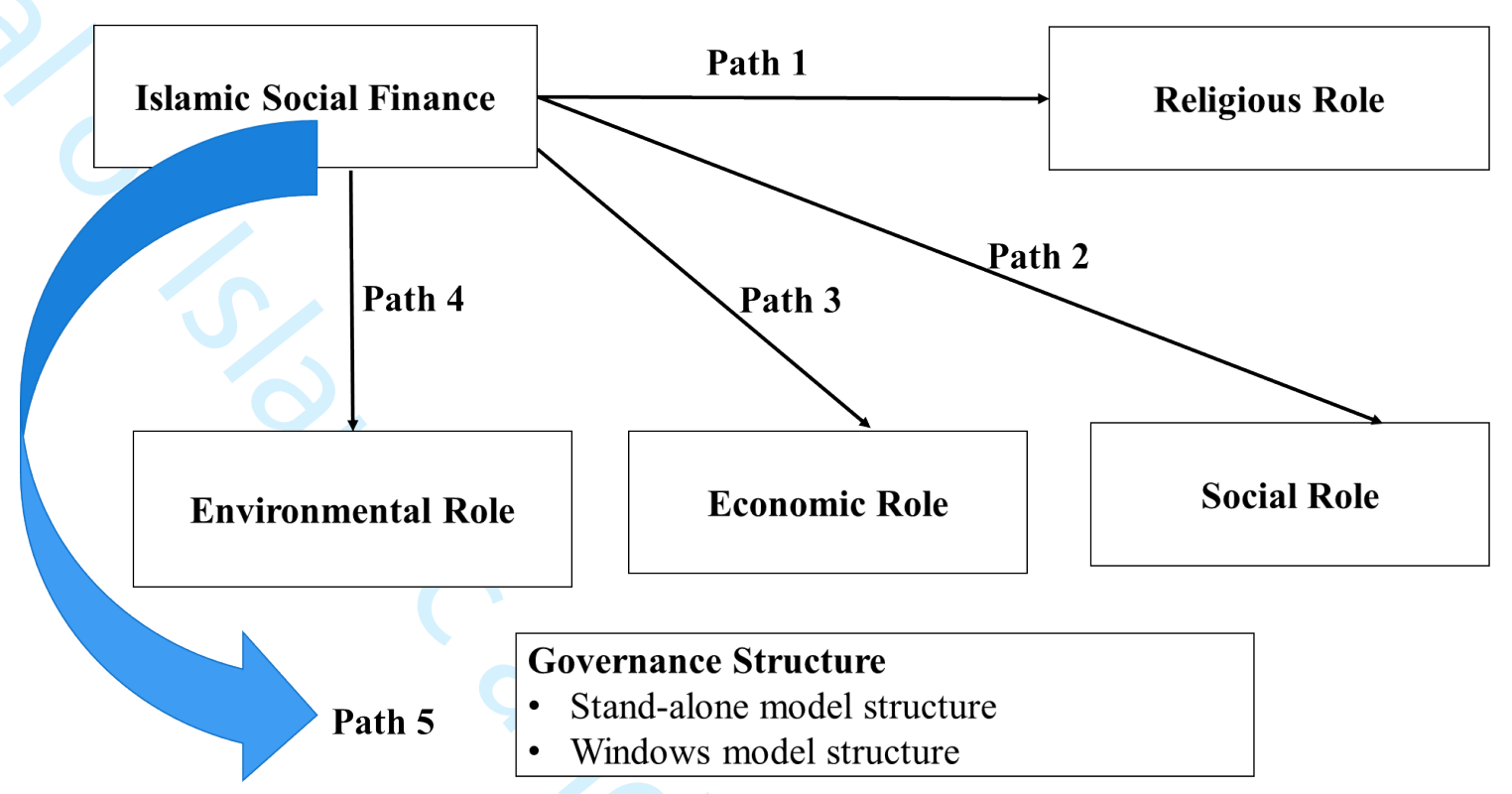

Figure 1 - Authors' Conceptual Framework 


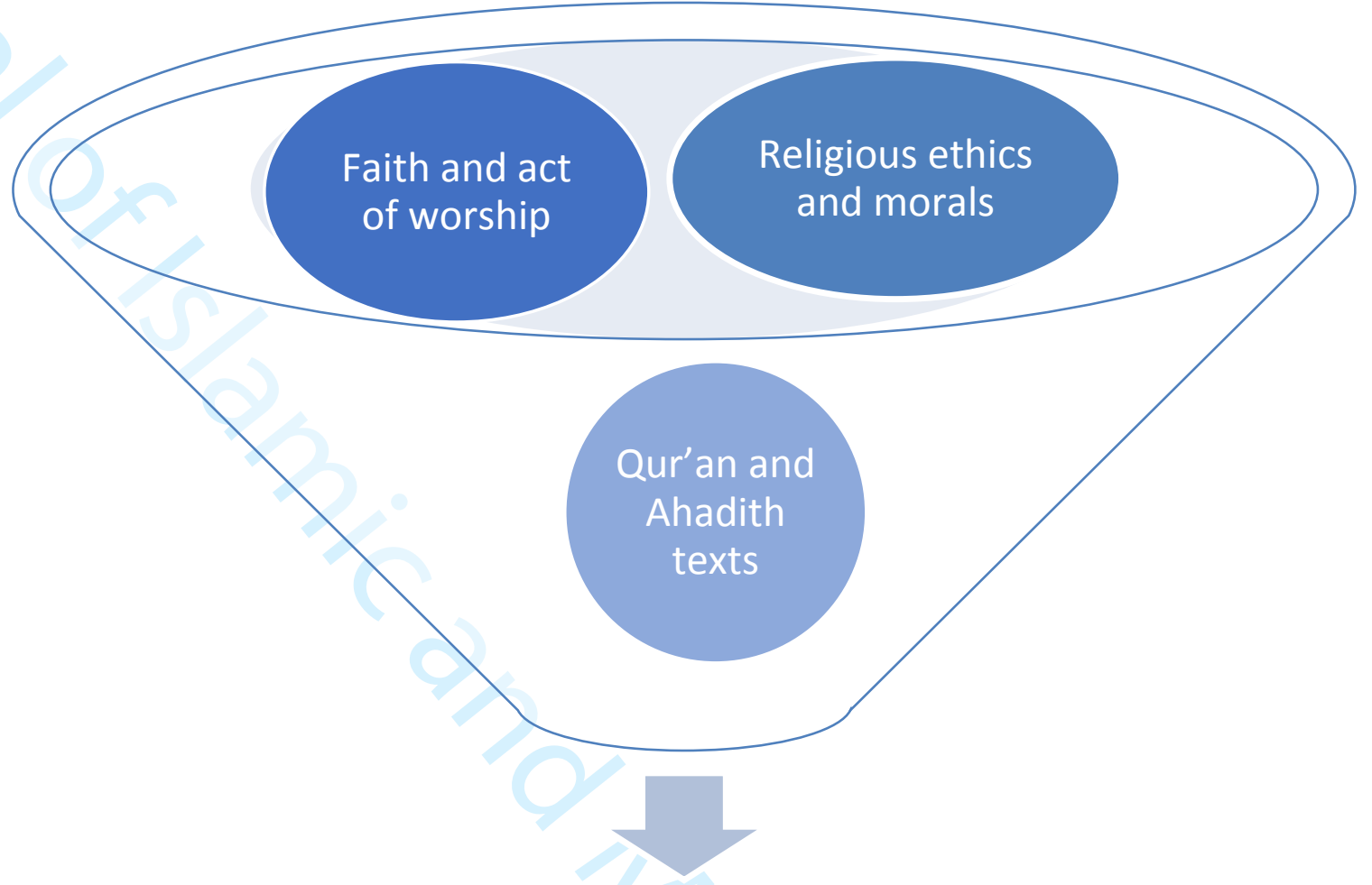

Sharing and caring for others

Figure 2: Religious motivating factors for the provision of social services 
Figure 3: Socio-economic motivating factors on the provision of social services 
Table 1 Face-to-face interviews with leaders of 3 IFBOs in Southwest Nigeria

\begin{tabular}{|c|c|c|c|c|}
\hline $\mathrm{S} / \mathrm{N}$ & DATE & ORGANIZATION & POSITION OF OFFICER & $\begin{array}{l}\text { NAME OF } \\
\text { OFFICER }\end{array}$ \\
\hline 1. & $9 / 6 / 15$ & $\begin{array}{l}\text { The Muslim Congress (TMC), } \\
\text { National Headquarters }\end{array}$ & President & TMCL-M1 \\
\hline 2. & $11 / 6 / 15$ & TMC, National Headquarters & Former Vice President & TMCL-M9 \\
\hline 3. & $11 / 6 / 15$ & $\begin{array}{l}\text { Hajj Mabrur Ventures Limited } \\
\text { (HMVL) }\end{array}$ & Managing Director/CEO & TMCL-M4B \\
\hline 4. & $16 / 6 / 15$ & $\begin{array}{l}\text { Al-Barakah Microfinance Bank } \\
\text { Limited (AMFBL) }\end{array}$ & Managing Director/CEO & TMCL-M10 \\
\hline 5. & $23 / 6 / 15$ & $\begin{array}{l}\text { Membership Empowerment } \\
\text { Committee, Ansar-Ud-Deen Society } \\
\text { (ADS) }\end{array}$ & Chairperson & AUDL-M3 \\
\hline 6. & $24 / 6 / 15$ & ADS, National Headquarters & $\begin{array}{l}\text { National Imam \& Head of } \\
\text { Mission }\end{array}$ & AUDL-M2 \\
\hline 7. & $27 / 6 / 15$ & HMVL & Chairman & TMCL-M4A \\
\hline 8. & $30 / 6 / 15$ & ADS, Lagos Branch & Branch Secretary & AUDL-M5 \\
\hline 9. & $30 / 6 / 15$ & NASFAT National Headquarters & National Education Officer & NAL-M3 \\
\hline 10. & $30 / 6 / 15$ & $\begin{array}{l}\text { NASFAT Agency for Zakat \& } \\
\text { Sadaqat (NAZAS) }\end{array}$ & General Manager & NAL-M5 \\
\hline 11. & $2 / 7 / 15$ & $\begin{array}{l}\text { TAFSAN Tours \& Travels Ltd } \\
\text { (TTTL) }\end{array}$ & Managing Director & NAL-M2 \\
\hline 12. & $3 / 7 / 15$ & $\begin{array}{l}\text { Human Concern Foundation } \\
\text { International (HCFI) }\end{array}$ & Executive Director & TMCL-M6 \\
\hline 13. & $5 / 7 / 15$ & ADS, National Headquarters & $\begin{array}{l}\text { National Education } \\
\text { Secretary/Provost, ADS College } \\
\text { of Education }\end{array}$ & AUDL-M1 \\
\hline 14. & $6 / 7 / 15$ & NASFAT National Headquarters & National Administrative Officer & NAL-M4 \\
\hline 15. & $8 / 7 / 15$ & ADS Clinics, Lagos & Chairman, Medical Board & AUDL-M4 \\
\hline 16. & $11 / 7 / 15$ & The Solace Hospital (TSH) & Medical Director & TMCL-M3 \\
\hline 17. & $16 / 7 / 15$ & Zakat \& Sadaqat Foundation (ZSF) & Operations Manager & TMCL-M5 \\
\hline 18. & $20 / 7 / 15$ & Vanguards Academy (VA) & Chairman, Management Board & TMCL-M8B \\
\hline 19. & $20 / 7 / 15$ & Vanguards Academy (VA) & Principal & TMCL-M8A \\
\hline 20. & $1 / 8 / 15$ & Aysh Ventures Limited & Chairman & TMCL-M2 \\
\hline 21. & $3 / 8 / 15$ & $\begin{array}{l}\text { Social Advocacy Project of Al- } \\
\text { Mu'minaat (SAP) }\end{array}$ & National Coordinator & TMCL-M7 \\
\hline 22. & $5 / 8 / 15$ & NASFAT Women Group & $\begin{array}{l}\text { National Women Affairs } \\
\text { Secretary }\end{array}$ & NAL-M1 \\
\hline 23. & $13 / 8 / 15$ & Fountain University, Osun (FUO) & Ag. Vice Chancellor & NAL-M6 \\
\hline
\end{tabular}




\title{
The Role of Islamic Social Finance in Societal Welfare: A Case Study of Selected IFBOs in Southwest Nigeria
}

\begin{abstract}
The paper examines the role of Islamic social finance (ISF) instruments such as Zakah, Sadaqah, and Awqaf in the provision of social services by Islamic faith-based organizations (IFBOs) in Nigeria. This study is based on data collected from the leaders of 3 active IFBOs: The Muslim Congress, NasrulLahi-L-Fatihi Society of Nigeria and Ansar-ud-Deen Society of Nigeria. Data from the interviews were analyzed using content and narrative analyses. The findings indicated faith in the Unseen God, scriptural texts and socioeconomic factors as major factors that accounted for the IFBOs' concerns for social services. The funding strategies used by the IFBOs to provide social services include Zakah, Awqaf (endowments), Sadaqah (voluntary donations) and gifts. Findings also showed that the IFBOs have efficient operational structures (Windows and Stand-Alone models) that align with the stakeholder theory of corporate governance. Finally, the findings also revealed the challenges facing the IFBOs, such as inadequate funding, dearth of manpower, uncooperative attitude of Muslims and attitudinal behaviour of givers and takers. The study has contributed to a better understanding of the role of ISF instruments in the provisions of social services by IFBOs; an area that is largely under researched.
\end{abstract}

Keywords: Faith-based organizations, Islamic social finance, Social services, Zakah, Sadaqah, and Waqf 


\subsection{Introduction}

Globally, the government of every sovereign nation is entrusted the legal responsibility of providing social services or public goods such as security, education and healthcare to the people as these services constitute their fundamental human rights (Berry et al., 2004). But the reality is that governments especially in the developing countries have failed to meet the social and economic needs of the citizens. The emergence of Islamic Social Finance (ISF) and other faith-based organizations (FBOs) as development partners is strongly linked to the crisis of bad governance mentioned above, which engenders ineffective delivery of services to people in developing countries. Comparatively, the developed countries have largely succeeded in providing these basic social services; however, developing countries are struggling and in most cases default in the delivery of basic social services. For example, the 36 states in Nigeria are not meeting their statutory responsibilities, partly due to a great deal of variation in their capacity for governance which has not improved the quality of life of the citizens (Harande, 2009). ISF is apparently similar to the conventional social finance as both serve as social security nets for the disadvantaged and marginalized members of the society. The only difference is that ISF mode of operations and its instruments are strictly guided by the established principles of Maqasid al-Shari'ah (Zain \& Ali, 2017). Poor financial inclusion or underutilization of ISF instruments could be one of the reasons for the deficiencies of social services in Southwest Nigeria. To bridge the governance gaps created by the inability of governments to meet the basic social service needs of their citizens, the United Nations came up with the sustainable development goals to tackle impending global challenges such as poverty, hunger, education, gender equality, clean water, economic empowerment, infrastructure provision, inequality and sustainable communities (Lucas et al., 2014). Civil societies including FBOs can intervene to augment the role of government to provide services to the impoverished or poor community (Beilefeld \& Cleveland, 2013). This study investigated the use of ISF instruments by IFBOs to help in the provision of services to the poor.

The advent of FBOs dates back to the era of colonialism. At that time, religious organizations were in vogue as a means to establish colonial power and transform the identity of the colonized peoples (Abuyuan, 2006). Presently, religious organizations have taken the form of special interest groups known as FBOs. In Nigeria, where the proportion of Muslims is $53.5 \%$, Christians $45.9 \%$ and $0.6 \%$ for indigenous beliefs (CIA, 2018), the Muslim and Christian FBOs have a long history of provision of social and humanitarian services, especially 
for disadvantaged people that are displaced by ethno-religious conflicts in volatile areas in the country (Odumosu et al., 2009). Early FBOs among the Muslim community in Nigeria include the Ahmadiyya and Ansar-Ud-Deen Societies, who were concerned with the provision of Western education combined with Islamic education (Kenny, 1979). Similarly, the apex body for all IFBOs in Nigeria, the Nigerian Supreme Council for Islamic Affairs (NSCIA), place high premium on educational matters and strives to ensure that all IFBOs are fairly treated (Mbachirin, 2006). A study indicates that some states and/or FBOs in Nigeria such as Zamfara, Sokoto, Kano, Katsina and Lagos, among others do collect and disburse Zakah funds voluntarily contributed by Zakah payers (Dogarawa, 2010). The research problem that created gaps that this current study intends to fill is explained hereunder. As mentioned earlier, the Muslim and Christian FBOs in Nigeria have a long history of provision of social and humanitarian services, but the social and humanitarian services provided by the FBOs are largely unacknowledged and under-reported (Orji, 2011). Also, while much recognition is given to the role of government, private sector organizations and the public sector in providing basic social services, the reverse has been the case on the socio-economic contributions of FBOs which will be discussed in the next section.

In view of the foregoing foundational problems of IFBOs in Nigeria, the research problem that is of interest is to examine the role of ISF instruments such as Zakah, Sadaqah, and Waqf in the provision of social services by IFBOs in Nigeria. The specific research questions are: (a)What are the motivating factors that influence the delivery of social services? (b) What is the type of governance structure used by the delivery of social services? (c) What are the funding strategies of ISF? Overall, there are six (6) sections in this study. Section 1 provides a concise introduction to the study. Section 2 explores the literature for concepts that underpin the study. Section 3 explicates the conceptual framework and development of propositions on role of ISF in the delivery of social services. Section 4 explains in details the methodological tradition of qualitative research as it relates to this study. Section 5 presents the results and discussions of the findings. Section 6 concludes with research implications and recommendations. 


\subsection{Literature Review}

\section{$2.1 \quad$ FBOs and their motivations}

The increasing recognition and appreciation given to the services being rendered by FBOs as development partners in the world has strengthened their commitments to give more to less-privileged communities (Nwokoro, 2017). For instance, the advice of the Commission for Africa (2005:27) that "for the African state to become effective, it needs to understand what it is about religion that builds loyalty, creates infrastructure, collects tithes and taxes, and fosters a sense that it delivers materials as well as spiritual benefits" underpins the positive contributions of FBOs in development. Religion is a powerful motivating force in development, utilizing spiritual teachings and practices to promote attitudinal change, with emphasis on concepts such as compassion and service; unity and interconnectedness; and justice and reconciliation (Einolf, 2011) which is the first theme of this study.

Due to different FBOs in the world, their activities and services vary and are diverse (Beilefeld \& Cleveland, 2013). Some of these activities include but are not limited to humanitarian services (Ferris, 2011); social welfare services (Cinnamon Network, 2016); microfinance and long-term development (Tomalin, 2012).

A study indicates that the religious beliefs of individuals are connected to economic development (Jong, 2008), just as the religious faiths of FBOs are linked with the provision of public goods and services. This has manifested in several ways, where FBOs engage actively in anti-poverty and social justice services. Boender (2015) also reinforced this argument that religious communities are known for their wide range of volunteers motivated by faith in God to render help to the poor. Another study suggests that such services carried out by IFBOs are meant to meet the needs of the less-privileged and vulnerable people with ISF instruments (Sesric, 2019), the second theme of this study, which will be examined in the next section.

\subsection{Financing activities of IFBOs}

One of the alternative sources of funding for social services but grossly underresearched is the ISF instruments utilized by IFBOs to "provide sustainable solution to reducing humanitarian funding gaps, help to reduce the vulnerability of people, alleviate human suffering and expand the opportunities for recovery." (Sesric, 2017:17). Of the various ISF 


\subsubsection{Zakah Instrument}

Zakah is one of the pillars of Islam and ISF instrument for entrepreneurial and empowerment of the less privileged in order to combat poverty and enhance welfare in the society (Beik \& Arsyianti, 2016). The word Zakah in Arabic is the infinite of the verb zakaa, meaning 'to grow, to purify and to increase' (Al-Qardawi, 1999). Juristically, it refers to the determined share of wealth taken from specific types of wealth when they reach a specific amount at a specific time, which must be spent on specific categories in specific ways (Zulfiqar, 2011). Zakah is institutionalized to mitigate social inequalities in the society and promote social justice (Widodo, 2019; UN, 2015). Be that as it may, poverty is on the increase in Nigeria and more rampant in the northern region where there are several Zakah institutions set up by not less than twelve states saddled with the management of Zakah and none in the south except voluntary organizations such as Zakat and Sadaqat Foundation with its headquarters in Lagos State (Obaidullah \& Shirazi, 2015). Every Muslim having resources beyond a minimum threshold (nisab) is liable to pay Zakah rate of $2.5 \%$ on annual basis and its disbursement should be in accordance with the rules delineated by Allah in Qur'an 9:60. The next section focuses on Waqf as instrument of ISF.

\subsubsection{Waqf Instrument}

Awqaf which is the plural of Waqf, is an important institution in the Islamic socioeconomic system used to address the needs of the poorest people, as well as boost the economic growth of society (Khairi et al., 2014; Zuki, 2012). Linguistically, Waqf means to hold, confinement or prohibition. Awqaf is technically a charity in perpetuity, which entails holding 
certain property and preserving it for the limited benefit of certain philanthropic purposes (Hassan, 2010). Waqf is distinct from ordinary sadaqah in the sense that it provides for flow of benefits on a sustained basis (Obaidullah \& Shirazi, 2015), thus, regarded as Sadaqah Jariyyah (ongoing charity). Awqaf, which used to apply to non-perishable assets, now applies to Cash Waqf through cash money which can be used to generate more funds and its profits invested in a wide spectrum of social investment (Mannan, 2018).

According to Obaidullah \& Shirazi (2015), there are two dimensions to the management of Waqf which is governed by the basic principles of perpetuity, inalienability and irrevocability. The first dimension is the preservation of the Waqf asset against usurpation by any parties as well as ensuring its continued usage so that its benefits continue to flow to the intended beneficiaries. While the second dimension is the Waqf development. This refers to the enhancement of the Waqf assets and its future benefits to the intended beneficiaries. Furthermore, depending on the institutionalized Waqf, be it Waqf al-khairy or Philanthropic (Social) Waqf or Waqfal-ahli (Family Waqf) or Waqfal-mushtarak (Jointly owned Waqf), the basic elements of Waqf must be provided in the deed of Waqf. These Waqf elements are the Waqif (Endower) which must be clearly stated, Mawquf (the Endowed Asset) and Mawquf Alaihi (Beneficiary) (Obaidullah \& Shirazi, 2015). The next section will address the ordinary Sadaqah as another ISF instrument.

\subsubsection{Sadaqah Instrument}

The term Sadaqah is derived from the word sidq (sincerity), which is truthfulness in realizing declared belief in action (Al-Qardawi, 1999) and which serves as a sign of sincerity. Technically, the term Sadaqah means worshipping Allah by voluntary charity, as understood in the economic literature (Lambarraa \& Riener, 2012). In other words, it implies giving any goods and funds for the sake of God sincerely and not for gaining praise or recognition from others.

\subsection{Organizational structures and corporate governance}

FBOs are becoming more conscious of their activities, accountability and need for effective service delivery to poor and deprived communities (Kapiriri et al., 2000). In developing countries, these organizations are determined not only to be responsive, but also transparent and accountable to their stakeholders. 


\subsubsection{Models of organizational structure}

FBOs typically have some degree of affiliation with a religious constituency, and it is this religious affiliation that differentiates them from their secular counterparts (Ferris, 2011). This may include welfare services supported by local groups or congregations and independent welfare organizations that are affiliated with one or more faith communities (Sinha, 2013). Furthermore, there are other FBOs which may operate independently of institutional religion and have only informal connections with religious hierarchies (Deines, 2008), although they may have had a more formal relationship previously.

Some studies suggest that some of the social services of FBOs which originated from the US focused on initiatives provided by local faith congregations (Boddie \& Cnaan, 2006), particularly from those associated with Protestant forms of Christianity (Unruh \& Sider, 2005). However, some religions such as Islam and Catholicism have more of a propensity to develop centralized services, which may be organized on a national or regional basis (Sinha, 2013). Hence, within a nation such as the US, it has been proposed that models for analysing Protestant faith-based initiatives may have limited utility in other settings (Smith \& Sosin, 2001). In contrast to the US, FBOs in Nigeria are mostly linked to religious federating organizations with local or national structures for both Muslims and Christians such as the Christian Association of Nigeria, Pentecostal Fellowship of Nigeria, Nigerian Supreme Council for Islamic Affairs and Jama'atu Nasr il-Islam (Odumosu et al., 2009).

A key aspect of organizational structures concerns decision-making processes within organizations. It may be important that the leadership is both skilled in managing a welfare agency and that there are processes reflecting the religious belief of the religious organization (Schneider, 2013). Whereas in some FBOs the major decisions are made by management groups controlled by the religious organization, in others, the supporting group may be entitled to nominate some but not all members of a board of management. Furthermore, there may be policies and procedures as to how many board members are required to be co-religionists (Sinha, 2013).

\subsubsection{Stand-alone model structure}

The stand-alone type of organizational structure encourages FBOs to operate independent of their parent body. FBOs adopting such a model are autonomous, though they 
report their programmes and projects to their Board of Directors (BOD) periodically. The managements of such organizations are encouraged to seek clarifications and obtain approval from the BOD in their service delivery.

\subsubsection{Windows model structure}

The windows model structure does not confer autonomy to the FBOs, because such organizations operate under the direct supervision of their parent body as standing committees and they also periodically render an account or give reports of their activities to the executive council or management team of the parent body.

\subsection{Challenges faced by FBOs}

Notwithstanding the good performance of FBOs, critics of their contributions have noted that several FBOs, especially the smaller ones, lack professional expertise and are fraught with low capacity and ineffectiveness to deliver their services (Goldsmith et al., 2006). Moreover, there is a growing demand for increased accountability and efficiency on the part of FBOs, especially as critics have argued that there is no empirical evidence to support claims that FBOs are more successful and effective in their delivery of services than the secular organizations (Wilson, 2003). Also, the congregational staff and volunteers of FBOs lack the required skills, technical/professional knowledge and quality time required to successfully carry out community development projects. Further, most FBOs lack the management capacity required to leverage government grants for executing their community development projects. In addition, some authors posit that the FBOs, like secular NGOs, are not immune to dishonesty. Some of them manifest management and accountability shortcomings, and thus, have been found guilty of improprieties such as mismanagement of funds, fraud, corruption and embezzlement, among others (Gilbelman \& Gelman, 2002).

Furthermore, opponents of FBOs have accused them of bias and prejudice towards the poor and needy whose faiths are not the same with those of the providers of humanitarian and social services, thereby excluding them from their services. In this context, critics argue that some FBOs - such as Islamic and Jewish organizations - are known for working exclusively with their own religious groups (Benedetti, 2006), while some Christian organizations also run an exclusive organization in terms of their staff recruitment policies. For instance, the "personnel policy" of the Salvation Army emphasizes that whoever is to be recruited as staff 
In Figure 1, we depict and operationalize the relationship of the key concepts in our conceptual framework, which include the following: (i) Path 1: how ISF influence the delivery of social services through religious factor, (ii) Path 2: how ISF influence the delivery of social services through social factor (iii) Path 3: how ISF influence the delivery of social services through economic factor; (iv) Path 4: how ISF influence the delivery of social services through religious factor; (v) Path 5: For the delivery of social services, the ISF often adopt the stand-alone model structure and/or windows model structure.

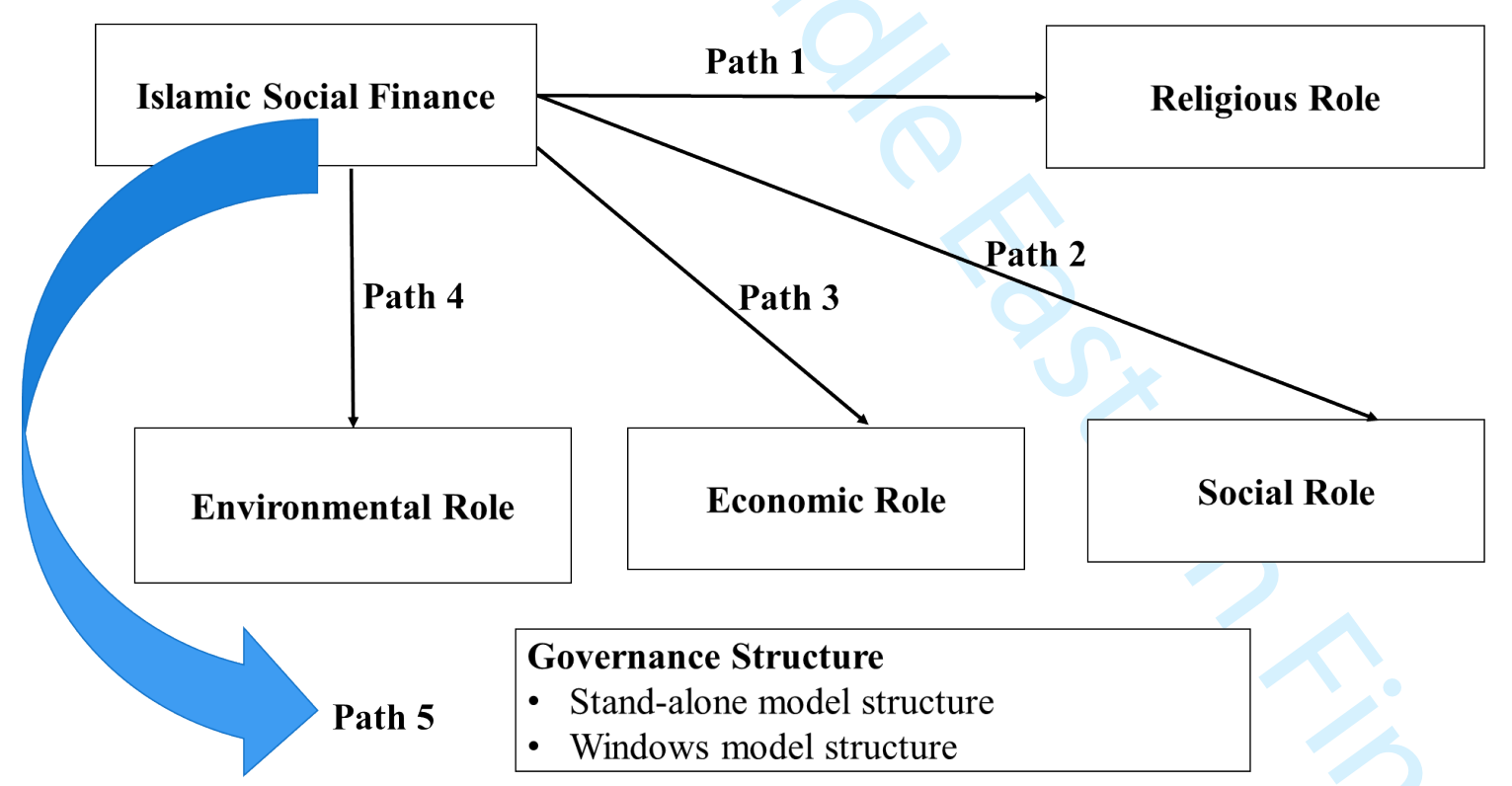

Figure 1: Authors' Conceptual Framework

A number of scholars noted that religion and self-driven volunteers are powerful motivating forces in development as pointed out in section 2.1. All these motivating factors boost delivery 
of social services as well as making service delivery cost effective and sustainable (Baiyeri, 2013).

The religious, social, economic and environmental factors that influence the operations of ISF in the delivery of public goods to the society is supported by the Maududian affirmative Islamic revivalism theory and Theory of Islamic Revivalism. The Maududian affirmative Islamic revivalism theory argues that Muslims with more knowledge, understanding and exposure to the provisions of the Qur'an and Sunnah are strongly motivated to revive their religion to meet the contemporary needs of the people. Islamic revivalism on the other hand is simply a reaction to certain issues found undesirable, unethical and repulsive in the society, and providing ethical solutions to them. Some of the issues that made Islamic revivalism imperative in the contemporary times include: (a) negative onslaught of modernity, (b) unfulfilled aspirations of the citizens and (c) increasing level of impoverishment and income inequality (Raimi, 2015). When applied to the role of ISF, it helps to complement the efforts of government through the fulfillment of aspirations of the citizens and reducing level of impoverishment and income inequality in the society. Moreover, the religion of Islam calls for a comprehensive development of an economy, and as a comprehensive way of life it puts great emphasis on social welfare especially the quest to maintain social justice, equity, and poverty among the Muslim faithful (Biancone \& Radwan, 2019).

Based on the diverse viewpoints above on the four factors that underpin the role of ISF in the delivery of social services, the following five propositions have been advanced:

Proposition 1: Religious factor especially Faith in the Unseen God motivates ISF to deliver social services.

Proposition 2: Social factor especially commitment towards promoting social justice, equity motivates ISF to deliver social services.

Proposition 3: Economic factor especially commitment towards promoting economic empowerment and income inequality motivates Islamic Social Finance to deliver social services.

Proposition 4: Environmental factor especially desire towards rural development and rehabilitation motivates ISF to deliver social services. 
Proposition 5: For the delivery of social services, the ISF often adopt the stand-alone model structure and/or windows model structure.

\subsection{Methodology}

Following the methodological tradition and practice in qualitative research, 147 IFBOs were identified from an unpublished database of an IFBO with wide spread operations, mostly in the Southwest Nigeria (Zakat and Sadaqat Foundation) and a telephone interview questionnaire was conducted to elicit their participation in the fieldwork. The purpose of the telephone interview was to ascertain their true existence and social services provision. Findings from the telephone interviews revealed that 105 organizations declined to participate because they were not directly involved in the provision of social services. Of these, 34 IFBOs only existed in name but had no programmes/projects that were evidence based while from the remaining, a sample of 3 active IFBOs (TMC, NASFAT and ADS) whose services were relevant to the use of ISF to provide social services was selected for the face-to-face interviews. This resulted into 23 interviews (TMC 12; NASFAT 6 and ADS 5) and 13 case study documents administered between 9 June and 13 August 2015 as shown in Table 1.

Table 1 Face-to-face interviews with leaders of 3 IFBOs in Southwest Nigeria

\begin{tabular}{|c|c|c|c|c|}
\hline $\mathrm{S} / \mathrm{N}$ & DATE & ORGANIZATION & POSITION OF OFFICER & $\begin{array}{l}\text { NAME OF } \\
\text { OFFICER }\end{array}$ \\
\hline 1. & $9 / 6 / 15$ & $\begin{array}{l}\text { The Muslim Congress (TMC), } \\
\text { National Headquarters }\end{array}$ & President & TMCL-M1 \\
\hline 2. & $11 / 6 / 15$ & TMC, National Headquarters & Former Vice President & TMCL-M9 \\
\hline 3. & $11 / 6 / 15$ & $\begin{array}{l}\text { Hajj Mabrur Ventures Limited } \\
\text { (HMVL) }\end{array}$ & Managing Director/CEO & TMCL-M4B \\
\hline 4. & $16 / 6 / 15$ & $\begin{array}{l}\text { Al-Barakah Microfinance Bank } \\
\text { Limited (AMFBL) }\end{array}$ & Managing Director/CEO & TMCL-M10 \\
\hline 5. & $23 / 6 / 15$ & $\begin{array}{l}\text { Membership Empowerment } \\
\text { Committee, Ansar-Ud-Deen Society } \\
\text { (ADS) }\end{array}$ & Chairperson & AUDL-M3 \\
\hline 6. & $24 / 6 / 15$ & ADS, National Headquarters & $\begin{array}{l}\text { National Imam \& Head of } \\
\text { Mission }\end{array}$ & AUDL-M2 \\
\hline 7. & $27 / 6 / 15$ & HMVL & Chairman & TMCL-M4A \\
\hline 8. & $30 / 6 / 15$ & ADS, Lagos Branch & Branch Secretary & AUDL-M5 \\
\hline 9. & $30 / 6 / 15$ & NASFAT National Headquarters & National Education Officer & NAL-M3 \\
\hline 10. & $30 / 6 / 15$ & $\begin{array}{l}\text { NASFAT Agency for Zakat \& } \\
\text { Sadaqat (NAZAS) }\end{array}$ & General Manager & NAL-M5 \\
\hline 11. & $2 / 7 / 15$ & $\begin{array}{l}\text { TAFSAN Tours \& Travels Ltd } \\
\text { (TTTL) }\end{array}$ & Managing Director & NAL-M2 \\
\hline
\end{tabular}




\begin{tabular}{|c|c|c|c|c|}
\hline 12. & $3 / 7 / 15$ & $\begin{array}{l}\text { Human Concern Foundation } \\
\text { International (HCFI) }\end{array}$ & Executive Director & TMCL-M6 \\
\hline 13. & $5 / 7 / 15$ & ADS, National Headquarters & $\begin{array}{l}\text { National Education } \\
\text { Secretary/Provost, ADS College } \\
\text { of Education }\end{array}$ & AUDL-M1 \\
\hline 14. & $6 / 7 / 15$ & NASFAT National Headquarters & National Administrative Officer & NAL-M4 \\
\hline 15. & $8 / 7 / 15$ & ADS Clinics, Lagos & Chairman, Medical Board & AUDL-M4 \\
\hline 16. & $11 / 7 / 15$ & The Solace Hospital (TSH) & Medical Director & TMCL-M3 \\
\hline 17. & $16 / 7 / 15$ & Zakat \& Sadaqat Foundation (ZSF) & Operations Manager & TMCL-M5 \\
\hline 18. & $20 / 7 / 15$ & Vanguards Academy (VA) & Chairman, Management Board & TMCL-M8B \\
\hline 19. & $20 / 7 / 15$ & Vanguards Academy (VA) & Principal & TMCL-M8A \\
\hline 20. & $1 / 8 / 15$ & Aysh Ventures Limited & Chairman & TMCL-M2 \\
\hline 21. & $3 / 8 / 15$ & $\begin{array}{l}\text { Social Advocacy Project of Al- } \\
\text { Mu'minaat (SAP) }\end{array}$ & National Coordinator & TMCL-M7 \\
\hline 22. & $5 / 8 / 15$ & NASFAT Women Group & $\begin{array}{l}\text { National Women Affairs } \\
\text { Secretary }\end{array}$ & NAL-M1 \\
\hline 23. & $13 / 8 / 15$ & Fountain University, Osun (FUO) & Ag. Vice Chancellor & NAL-M6 \\
\hline
\end{tabular}

Qualitative data from the three IFBOs was analysed using Auerbach's six-step approach of coding and analysis to understand their role in the provision of social services using ISF. The data from the interviews were analyzed using narrative analyses. The qualitative research method was preferred for this research because understanding and unveiling the themes listed above would better be achieved through interactive field interviews with IFBOs.

\subsection{Results/Synthesis of Findings and Discussions}

The synthesis and discussions of the findings oscillated around the four themes of the study, namely: factors motivating IFBOs; funding strategies of IFBOs in social service provision; efficiency and effectiveness of the organizational structures of IFBOs in social service interventions; and challenges faced by IFBOs in social service intervention. The next section focuses on the first theme.

\subsection{IFBOs 'Motivating Factors for Providing Social Services}

The study found that the three IFBOs are motivated to render social services by religious, social, economic and environmental factors. These IFBOs, as illustrated in Figure 2, affirm that Allah has enjoined Muslims in their scriptures (TMCL-M6, M9) to show concern 
to mankind (TMCL-M5). It is this religious factor that motivates the TMC to provide social services to people (TMCL-M3), because social services are considered a form of worship. One of the interviewees remarked as follows:

"We are actually worshipping God doing all these services and that's why we do them with zeal and enthusiasm because we see them as acts of worship..." (TMCLM1).

Similarly, the ADS and NASFAT provide services to the society for the purpose of promoting Islam and improving members' lifestyles spiritually through preaching, Islamic teachings, seminars and establishment of educational institutions such as Colleges of Education/Universities (AUDL-M2, M3, M4; AUDL-DC1 \& NAL -M6, NAL-DC1, DC2) to inculcate religious ethics into their members and non-members. Another factor is the desire to complement governments in providing basic social services to the people (TMCL-M2) as well as the need to promote inter-faith peace and understanding in a volatile country such as Nigeria (TMCL-M1; AUDL-M5), where people have misconstrued religion, thereby correcting the belief that Islam is synonymous with terrorism and insurgency. The spectrum of social, economic and environmental motivating factors includes wealth creation and human capital development, which these organizations believe are ways of paying back the society (TMCLM1; NAL-M4, M5; AUDL-M2, M3).

Furthermore, ADS like other IFBOs is motivated to provide social services because it aims to promote social justice, equity, income redistribution in the society, compassion and respect for humanity. It embarks on social services to uplift Islam and eradicate poverty by creating jobs, irrespective of religion (AUDL-M5; AUDL-DC2, DC3). In the area of education, the environmental factor that motivated NASFAT and ADS was the desire to respond to the deprivation of social services to Muslims by Christian missionaries (NAL-DC3 \& AUDLDC1). These services are further illustrated in Figure 3. 


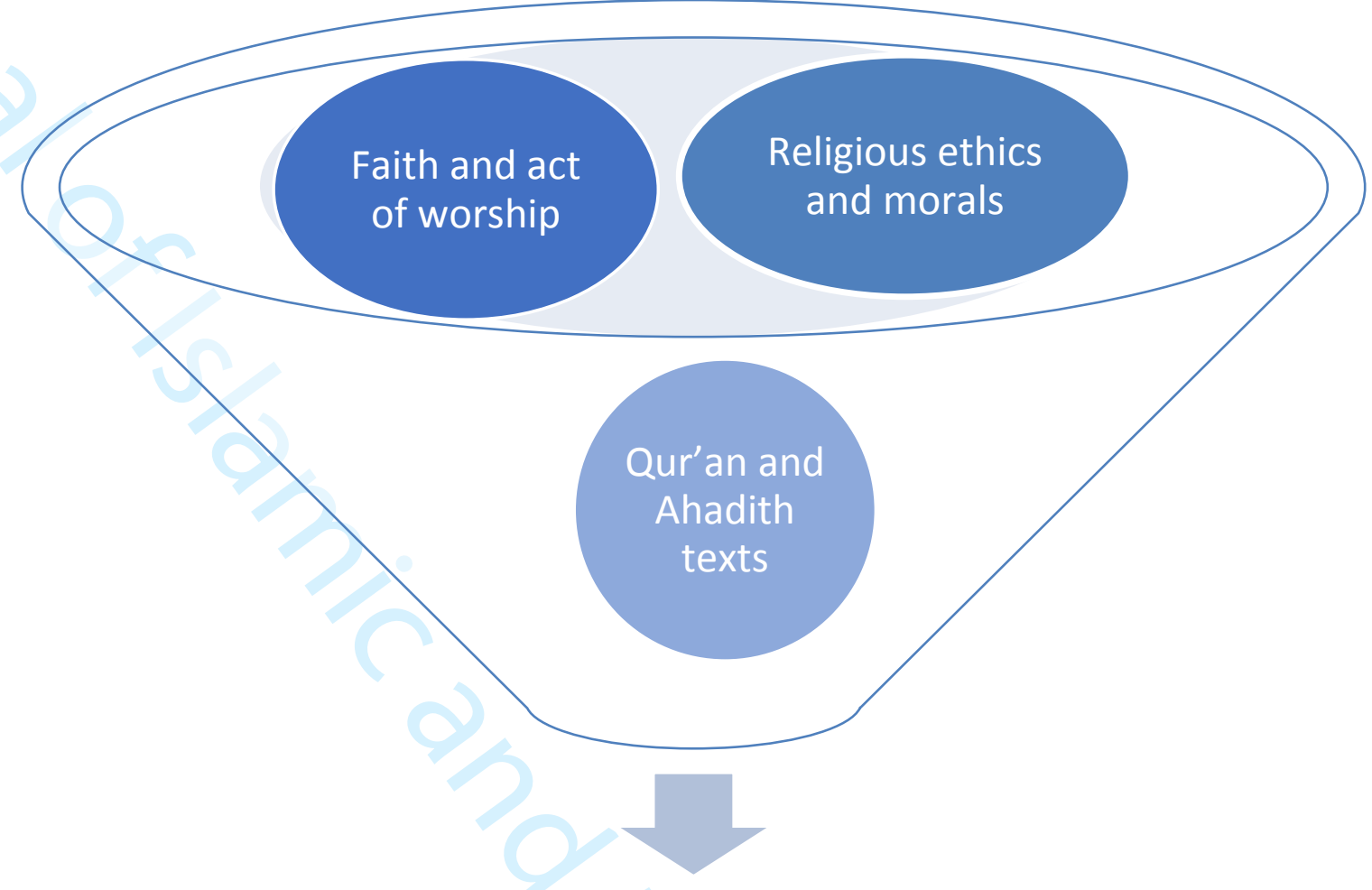

\section{Sharing and caring for others}

Figure 2: Religious motivating factors for the provision of social services

The findings on the motivating factors influencing delivery of social services are consistent with the four propositions under the conceptual framework, which indicate that: (a) Religious factor especially Faith in the Unseen God motivates ISF to deliver social services; (b) Social factor especially commitment towards promoting social justice, equity motivates ISF to deliver social services; (c) Economic factor especially commitment towards promoting economic empowerment and income inequality motivates ISFto deliver social services; (d) Environmental factor especially desire towards rural development and rehabilitation motivates ISF to deliver social services. The four propositions are further supported by the view of the Desmond Tutu Peace Foundation (2012), which reports that FBOs essentially focus on pastoral and charity works, which entail care of orphans, widow support services, care for strangers and social services for the suffering. These religious cum social services are foundational obligations in both the Islamic and Christian faiths (TMCL-M5; NAL-M4 and AUDL-M2, M3 \& AUDL-DC4). 
4

\section{Humanitarian gesture}

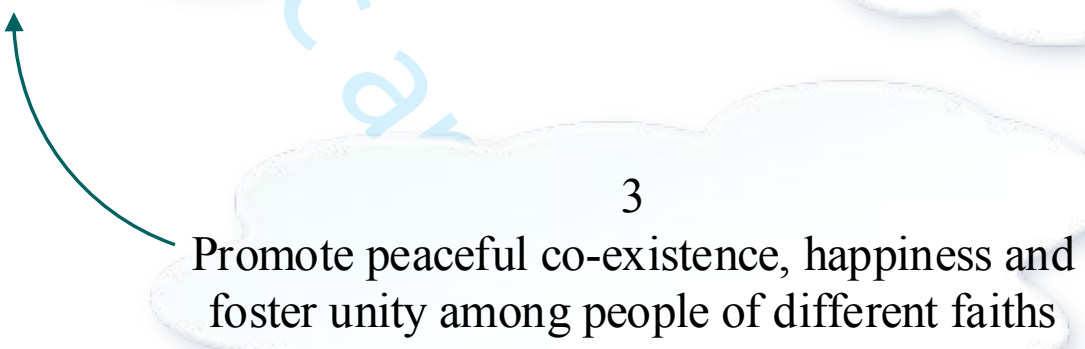

\section{Figure 3: Socio-economic motivating factors on the provision of social services}

Moreover, Lunn (2009) found that religion, spirituality and faith consistently play commendable roles in the past, present and future of development of communities, because FBOs create a vision of a better world that is not centered on economic factors and the "survival of the fittest" principle. In Muslim majority nations, the IFBOs are active in providing social services for the purpose of promoting social and economic development guided by religioninspired goals. The second theme of the study is addressed in the next section.

\subsection{Funding Strategies Adopted by IFBOs}

It was found that the three organizations interviewed have different but interrelated sources as their funding strategies for the social services they provide. For TMC, its activities are financed through grants, Sadaqah, Zakah, support from patrons and returns from investments in some business ventures (TMCL-M2, M4A, M4B, M5), funds realised from Awqaf (endowments) are deployed to provide some social services associated with the endowments (TMCL-M9). The organization also partners and collaborates with individuals 
and corporate organizations to organize special programmes such as entrepreneurship development projects, giving of grants for small scale enterprises and procurement of equipment for petty traders through a microfinance bank, among others (TMCL-M5, M7).

NASFAT funds its activities through donations from well-meaning Nigerians, captains of industry, and corporate bodies (NAL-M1, M3). While profit from its economic organ such as TTTL is deployed for the funding of programmes (NAL-M2), its NAZAS also provides funding for a number of social, welfare and community services (NAL-M5).

Regarding ADS, its funding strategies include donations from its wealthy members (AUDL-M1) which are also collected during its annual harvest, sales and award ceremonies (AUDL-M4). The organization also generates its income from taxes and levies imposed on its members (AUDL-M1). Besides, incomes from investment outlets of the organization such as Adson Water, Sideline Laboratory and Adson Travel Agency (ATA) for Hajj and Umrah pilgrims, it generates additional funds from Zakah and Sadaqah (AUDL-M3).

The findings on strategies for mobilising funds by the three IFBOs interviewed for this study are supported by previous studies and best practices of IFBOs (Mannan, 2018). The efficiency and effectiveness of the organizational structures, policies and procedures of the three IFBOs, which is the third theme of the study, will be discussed next.

\subsection{Organizational Structures, Policies and Procedures}

It was found that the three IFBOs have their autonomous organs supporting the parent organizations in carrying out social services (TMCL-M1; NAL-M4 \& AUDL-M1). This finding is consistent with the proposition 5 which stated that for the delivery of social services, the ISF often adopt the stand-alone model structure and/or windows model structure. In line with corporate governance best practice, the boards and appointed directors are constituted to provide efficient monitoring, supervisory and advisory functions to the management with a view to ensuring creation of shareholder value (De Andres \& Vallelado, 2008). These parent organizations and their autonomous organs have well-defined organizational structures, policies and procedures that are employed to carry out their social service interventions on a daily basis (TMCL-M1, M7; NAL-M3, M5 \& AUDL-M5. This finding aligns with the view in the literature that members of the BOD of corporate entities should be appointed for the 
purpose of monitoring the performance of the organizations with a view to ensuring that the interests of shareholders are protected within the agency theory of firms (Xie et al., 2003).

From the organizational policy angle, it was found that the three IFBOs have operational policies with checks and balances (TMCL-M2; TMCL-DC13, NAL-M3; NALDC1\& AUDL-M1). The IFBOs have in place the Board of Trustees (BOT), the National Executive Council (NEC), the State Executive Council (SEC) and Branch Executive Councils (BEC) (TMCL-M1; TMCL-DC12, NAL-M1 \& AUDL-M3). Different organs of the organizations also have specific policies guiding their activities (TMCL-M5; NAL-M5 \& AUDL-M5). For instance, ZSF prioritize its funding in the following order: Economic Empowerment-40\%; Medical Support-23\%; Educational Support-15\%; Welfare/Institutional Support-13\% and Community Projects-9\% (TMCL-M5). Its organizational structure consists of the following layers; the Advisory Board, which performs its role squarely in an advisory capacity to the BOD. The BOD is the highest decision-making organ of the Foundation, and it is responsible for the policy thrust, budget approval and overall disciplinary measures and control of the workforce of the Foundation. Next is the Management Board with seven members, with the Executive Director as the Chairman, the Board Secretary and five other members. TMC also uses its organs as a means of providing employment for its members who are qualified (TMCL-M4A).

NASFAT also has a corporate governance structure (NAL-M4). There exists a board with oversight functions over the executives, who are charged with the day-to-day running of the organization. Accounts are prepared and rendered with scrutiny by an external auditor approved by the board. The accounts are published in leading newspapers and copies are filed with the Corporate Affairs Commission (CAC) annually. There is the BOT, the Elders Council (EC), the Mission Board (MB) and the NEC. All Secretaries at the national level are members of NEC. The NEC makes decisions for the organization on behalf of members and other organs.

Similarly, ADS has a sound organizational structure at the National, State, Zonal, Branch and Division levels (AUDL-M1). In ensuring that the set religious and social objectives are achieved, the NEC of the organization put in place policies and procedures which all management committees charged with various social services follow in meeting the needs and expectations of the organization. It has notable committees on Education, Hospitals, Membership Empowerment and Women. All committees report to the NEC. The next section concludes with the fourth theme of the study, which is the challenges faced by the three IFBOs. 


\subsection{Challenges Faced by IFBOS in Providing Social Services}

It was found that the three IFBOs face a myriad of challenges. Though their challenges look similar, there are peculiar challenges linked to each of the three organizations. The major challenges facing TMC, NASFAT and ADS are attitudinal problems of human resources (TMCL-M5, M9, NAL-M1 \& AUDL-M3), which are the most difficult resources to manage within an organizational context. Related to the people management challenge is the finance problem. The three IFBOs were not able to fund their laudable programmes and projects as expected, because their members are financially incapacitated on account of the poverty situation of their members (TMCL-DC9, DC11, NAL-M1 \& AUDL-M1, M5). The income receives by the IFBOs from the services their organs render is never sufficient to provide more services. For example, TMC received $\$ 746,297,323$ (equivalent to $\$ 2,073,048.22$ US dollar) between 2011 and 2017 out of a cumulative budget of $\$ 805,289,600$ (equivalent to $\$ 2,236,916.20$ US dollar) for the said period. Between this period, the organization spent $\$ 248,405,384$ ( $\$ 690,014.97$ US dollar) on economic support services to 3,251 beneficiaries, $\$ 127,441,332$ ( $\$ 354,003.71$ US dollar) on health-related services to 412 less-privileged people and $\$ 17,472,202$ ( $\$ 48,533.90$ US dollar) on community services (water and sanitation), among others. The average deficit per year is $\$ 26,823,970.2$ (equivalent to $\$ 74,511.05$ US dollar), while the cumulative budget deficit for the said period was $\$ 58,992,277$ ( $\$ 163,867.44$ US dollar). The only period the organization operated budget surpluses were in 2013 and 2017 with an actual budget of $\$ 122,038,665$ (\$338,998.07 US dollar) as against a budget estimate of $\$ 68,577,600$ (\$190,494.33 US dollar) and an actual budget of $\$ 196,666,509$ (US\$546,298.73) as against a budget estimate of $\$ 175,000,000$ (\$486,112.42 US dollar), respectively (TMCL-DC11). Unfortunately, the rich are also selective in their choice of and amounts given out as donations (TMCL-M2). Whereas impactful social services are best done through sustained funding and permanent staff.

The fluctuations in the exchange rate in favour of the American dollar have also affected the operations of HMVL of TMC, TTTL of NASFAT and ATA of ADS (TMCLM4A, NAL-M2 \& AUDL-M1). The instability of the dollar has affected the pricing of Hajj and Umrah services, while crippling the operational policies of the managements of these agencies from time to time (AUDL-M5). With regards to geographical expansion, NASFAT has not been able to spread its services to many places in Nigeria, as it is unable to do so due to financial challenges. Similarly, financial constraints have inhibited TMC from being able to employ paid professionals to handle its activities for greater impact (TMCL-DC9; TMCL-M3, 
M6, NAL-M3 \& AUDL-M3). These challenges arise because FBOs suffer paucity of funds and professionals compared with full-fledged business organizations.

Besides, government policies on Islamic charity activities in Southwest Nigeria are not enabling, as there are no Acts of the State Houses of Assembly that give legal frameworks for the collection and distribution of Zakah as done by TMC, NASFAT and ADS (TMCL-M4B, M5, M8A, M8B \& NAL-M2), unlike what obtains in the Northern part of the country. This challenge has made it difficult for eligible Zakah payers to be assessed for the payment of Zakah. Related to evasion of Zakah payment is the apathy by philanthropists to support IFBOs (TMCL-M2) because of the fear of being linked to terrorism and insurgency, as the international community is beaming its searchlights on philanthropists and donors who fund terrorism (TMCL-M9, NAL-M4 \& AUDL-M2).

Another challenge that affects the three IFBOs is slow decision-making (TMCL-DC9 \& NAL-M4), because as IFBOs, some organizational decisions have to be taken by consensus, and consensus decisions by default pass through a chain of processes, therefore patience has to be exercised. Another challenge is impatience on the part of the public seeking spiritual, welfare and social services of these organizations (TMCL-M5 \& NAL-M5), whereas due process has to be observed by these IFBOs in meeting the needs and expectations of the requesting public. Also, the culture of volunteerism is lacking among Muslims in Nigeria (TMCL-DC9; TMCL-M6, NAL-M3 \& AUDL-M3).

Another challenge is the hostility from host communities. Some individuals prevent IFBOs from impacting positively on the poor inhabitants that need water and other humanitarian services under the pretext that the IFBOs' social actions would kill their businesses (TMCL-M2). Although these findings are both directly related to the challenges of IFBOs in Nigeria, they go a long way in affirming the reality of hostility towards some programmes of FBOs.

Finally, the challenge of media visibility inhibits IFBOs' services in Nigeria. Specifically, the beautiful and impactful services of TMC, NASFAT and ADS in the realm of spiritual, social, economic and environmental interventions are not well reported by media organizations (TMCL-M7 \& AUDL-M2). The little reportage that scaled through television or social media are fully paid for by these IFBOs. 


\subsection{Conclusion, Policy Recommendations and Implications}

This paper has highlighted the role of ISF instruments used by the three organizations to provide social services such as education, health, economic empowerment, community service, water and sanitation to the poor. The IFBOs are however challenged by financial, environmental, attitudinal, legal, political and visibility factors. While IFBOs in Southern Nigeria have funding constraints and other environmental challenges, the reviewed literature indicates that IFBOs in northern Nigeria enjoy some patronage from governments in terms of the enactment of legal frameworks for their operations with the help of ISF instruments such as Zakah, Sadaqah and Awqaf. Same cannot be said for Southwest Nigeria. This dichotomy portends both legal and operational implications for IFBOs in Southwest Nigeria. As regards the aforementioned, the operational implications that IFBOs may have to contend with include the challenge of ensuring that they (IFBOs) do not discriminate or become biased against the poor on the basis of their faith or religion, which may be different from that of the IFBOs. The major practical implication of this paper is that ISF has been reinvented as an ethical social welfare framework for supporting the disadvantaged members of the society with ISF instruments.

Finally, we recommend that further research and empirical investigation should be conducted on the viability or otherwise of ISF as catalyst for poverty reduction, wealth creation and enterprise development by ISF practitioners, NGOs and State government Zakah and Awqaf bodies and other stakeholders. In addition, NGOs and State government policy makers should enunciate policy statements that gives recognition to the role of IFBOs using ISF instruments in providing basic social services. Furthermore, ISF professionals and NGOs in the Southwest Nigeria should sponsor private Bills at the State Assemblies for the enactment of a legal framework to give meaning to their work as well as strengthen the IFBOs so that significant improvements can be made in their funding strategies and delivery of social services. 


\section{References}

Abuyuan, A. T. (2006). Faith-based organizations, international development agencies, and environmental management. Dissertation, University of California.

Al-Qardawi, Y. (1999). Fiqh Az-Zakah - A Comparative Study of The Rules, Regulations and Philosophy of Zakah in the Light of The Qur'an and Sunnah. London: Dar Al-Taqwa Ltd.

Baiyeri, H. B. (2013). The role of faith-based organizations (FBOs) in human development: A study of Kogi State. Dissertation of University of Nigeria, Nsukka. Retrieved at http://www.unn.edu.ng/publications/files/BAIYERI,\%20H.\%20B.pdf. on 30 ${ }^{\text {th }}$ April, 2017.

Beik, I. S. and Arsyianti, L. (2016). Measuring Zakat Impact on Poverty and Welfare Using CIBEST Model. Journal of Islamic Monetary Economics and Finance, 1(2), 141-160. https://doi.org/10.21098/jimf.v1i2.524

Benedetti, C. (2006). Islamic and Christian Inspired Relief NGOs: Between Tactical Collaboration and Strategic Diffidence? Journal of International Development 18(6); 849-859.

Berry, C., Forder, A., Sultan, S. and Moreno-Torres, M. (2004). Approaches to improving the delivery of social services in difficult environments. Poverty Reduction in Difficult Environments (PRDE) Working Paper, 3.

Biancone, P. P. and Radwan, M. (2019). Social finance and financing social enterprises: an Islamic finance prospective. European Journal of Islamic Finance, 1-9.

Beilefeld, W. and Cleveland, W. S. (2013). Faith-Based Organizations as Service Providers and their Relationship to Government, Nonprofit and Voluntary Sector Quarterly, 42(3), pp. 468-494.

Boddie, S.C. and Cnaan, R. A. (2006). Faith-Based Social Services: Measures, Assessments and Effectiveness. New York, NY: The Hawthorn Pastoral Press (co-published simultaneously as Journal of Religion \& Spirituality in Social Work, 25, [3/4]).

Boender, W. (2015). Volunteering in Religious Communities. 329-343. In Hustinx, L., Von Essen, J., Haers, J, Mels, S. (Eds.), Religion and Volunteering Complex, contested and ambiguous relationships, Springer International Publishing. 
CIA Nigeria Country FactBook., 2018. Retrieved at https:/www.cia.gov/library/publications/the-world-factbook/fields/401.html on $2^{\text {nd }}$ January, 2020.

Cinnamon Network. (2016). Cinnamon Faith Action Audit National Report. Retrieved at http://www.cinnamonnetwork.co.uk/wp-content/uploads/2019/10/26081-National-ReportCFAAR-20pp-2016-AW_hr.pdf on 11 th November, 2020.

Clarke, G. \& Jennings, M. (2008). Introduction in G. Clarke and M. Jennings (eds.) Development, Civil Society and Faith-Based Organizations. Bridging the Sacred and the Secular, Basingstoke: Palgrave Macmillan.

Commission for Africa. (2005). 'Our Common Interest: Report of the Commission for Africa,' March.

De Andres, P. and Vallelado, E. (2008). Corporate governance in banking: The role of the board of directors. Journal of Banking \& Finance, 32, pp. 2570-2580.

Deines, H. (2008). The Catholic worker movement: Communities of personal hospitality and justice, Social Work and Christianity, 35(4), 429-448.

Desmond Tutu Peace Foundation (2012). Emerging Role of Faith-Based Organizations in the Global Development. Retrieved at http://www.tutufoundationusa.org/2012/10/07/theemerging-role-of-faith-based-organizations-in-global-development/ on March 21, 2017).

Dogarawa, A. B. (2010). Achieving Equitable Wealth Distribution through the Institution of Zakah, Department of Accounting, Ahmadu Bello University (ABU), Zaria, Nigeria.

Einolf, C. (2011). The link between religion and helping others: The Role of Values, Ideas, and Language. Sociology of Religion, 72 (4), pp. 435-455.

Ferris, E. (2011). Faith and Humanitarianism: It's Complicated. Journal of Refuge Studies, 24 (3), pp. 605-625.

Gilbelman, M. and Gelman, S. R. (2002). Should we have faith in faith-based social services? Rhetoric versus realistic expectations. Nonprofit management and leadership, 13(1), pp. 4965. 
Goldsmith, S., Eimicke, W. B. and Pineda, C. (2006). Faith-Based Organization versus their Secular Counterparts: A Primer for Local Officials. Ash Center for Democratic Governance and Innovation, Harvard Kennedy School.

Harande, Y. I. (2009). Information services for rural community development in Nigeria. Library Philosophy and Practice (e-journal). University of Nebraska - Lincoln. Retrieved at http://digitalcommons.unl.edu/libphilprac/?utm_source=digitalcommons.unl.edu\%2Flibphilp rac\%2F271\&utm_medium=PDF\&utm_campaign=PDFCoverPages on 27th April, 2017.

Hassan, M. K. (2010). An Integrated Poverty Alleviation Model Combining Zakat, Awqaf and Microfinance. Seventh International Conference, The Tawhidi Epistemology: Zakat and Awqaf Economy, Bangi.

Jong, E. D., (2008). Religious Values as Economic Growth: A review and assessment of recent studies. NiCE Working Paper 08-111, November, Nijmegen Center for Economics (NiCE), Institute for Management Research, Radboud University, Nijmegen, Netherlands.

Kapiriri, M., Manyire, H., Hearn, J., Kanji, J. and N. 2000. An Assessment of DFID's Engagement with Civil Society in Uganda: Past Work and Current Shifts. Report to DFID. Kampala: DFIDEA Uganda.

Kenny, J. (1979). Christian-Islam Relations in Nigeria.Islamochristiana. 5, pp. 171-192.

Khairi, K. F., Aziz, M. R., Laili, N. H., Nooh, M. N., Sabri, H. and Ali Basah, M. Y. (2014). Human and Economic Development Through Share Waqf (WAQF Corporate): The Case of GLCS In Malaysia. Life Science Journal, 11(1): 104-110. Retrieved at http://lifesciencesite.com/Isj/life1101/015_21866life1101_104_110.pdf on 9th November, 2020.

Lambarraa, F. and Riener, G. (2012). On the Norms of Charitable Giving in Islam: A Field Experiment. Discussion Paper 59, Published by Dusseldorf Institute for Competition Economics (DICE), Dusseldorf, Germany.

Lucas, P., Kok, M. T. J., Nilsson, M. and Alkemade, R. (2014). Integrity Biodiversity and Ecosystem Services in Post-2015 Development Agenda: Goal Structure, Target Areas and Means of Implementation. Sustainability, 6, 193-216. 
Lunn, J. (2009). The Role of Religion, Spirituality and Faith in Development: a Critical Theory Approach. Third World Quarterly, 30(5), 937-951.

Mannan, M. A. (2018). Linking Islamic Commercial and Social Finance with Special Reference to Cash-Waqf as new strategy of interest-free micro-credit for family empowerment of the poor towards establishing World Social Bank: A Case Study Approach. Journal of Islamic Monetary Economics and Finance, Volume 3, Special Issue, pp. 1-24.

Mbachirin, A. T. (2006). The Responses of the Church in Nigeria to Socio-Economic, Political and Religious Problems in Nigeria: A Case Study of the Christian Association of Nigeria (CAN) PhD Dissertation, Waco, Texas: Baylor University.

Nwokoro, C. V. (2017). Assessing the Distinctiveness of Faith Based Organizations in the Development Sector in Nigeria, Journal of Humanities and Social Policy Vol. 3 No. 2.

Obaidullah, M. \& Shirazi, N. S. (2015). Islamic Social Finance Report 1436H: Jeddah, Saudi Arabia. Islamic Research and Training Institute (IRTI), 2015.

Odumosu, O., Olaniyi, R. and Alonge, S. (2009). Mapping the Activities of Faith-Based Organizations in Development in Nigeria.Working Paper 38, Religion and Development Programme, International Development Department, University of Birmingham, UK.

Orji, N. (2011). Faith-based aid to people affected by conflict in Jos, Nigeria: an analysis of the role of Christian and Muslim organizations. Journal of Refugee Studies, 24(3), 473-492.

Raimi, L. (2015). Waqf and Zakah as Social Safety Nets for Poverty Reduction in Nigeria. WIEF-UiTM Occasional Papers, 2nd EDITION, 89-103.

Raimi, L., Shuaib, A., Shokunbi, M. O. \& Akosile, O. K. (2016). Financial inclusion in Nigeria through Zakat and Waqf. International Journal of Management Sciences and Humanities, Volume 4, Number 1, pp.68-90.

Schneider, J. A. (2013). Comparing Stewardship Across Faith-Based Organizations. Nonprofit and Voluntary Sector Quarterly, 42, 517-539.

Sesric. (2017). Humanitarian Crises in OIC Countries, Drivers, Impacts, Current Challenges and Potential Remedies. Retrieved at https://www.sesric.org/publications-detail.php?id=412 on $9^{\text {th }}$ November, 2020. 
Sesric. (2019). OIC Forum on Islamic Social Finance in Jakarta. Retrieved at https://www.sesric.org/event-detail.php?id=2283 on $9^{\text {th }}$ November, 2020.

Sinha, J. W. (2013). Unintended consequence of the faith-based initiative: Organizational practices and religious identity within faith-based human service organizations. Nonprofit and Voluntary Sector Quarterly, 42, 563-582.

Tomalin, E. (2012). Thinking about faith-based organizations in development: where have we got to and what next? Development in Practice, 22(5-6), pp; 689-703.

United Nations. (2015). Is Islamic charitable giving a promising resource for future humanitarian assistance? Retrieved at https://reliefweb.int/report/world/islamic-charitablegiving-promising-resource-future-humanitarian-assistance on $9^{\text {th }}$ November, 2020.

United Nations. (2016). Too important to fail - addressing the humanitarian financing gap, High-Level Panel on Humanitarian Financing Report to the Secretary-General. Retrieved at https://reliefweb.int/updates?search+Too $\% 20$ important $\% 20$ fail $\% 20$ addressing $\% 20$ the $\% 20$ hu manitarian\%20financing\%20gap on $9^{\text {th }}$ November, 2020.

Unruh, H. and Sider, R. (2005). Saving souls, serving society: understanding the faith factor in church-based social ministry. Oxford, New York: Oxford University Press, pp. 323.

Widodo, A. (2019). THE ROLE OF INTEGRATED ISLAMIC COMMERCIAL AND SOCIAL FINANCE IN REDUCING INCOME INEQUALITY IN INDONESIA. Journal of Islamic Economics and Finance, Vol 5, No.2, pp 263-286.

Wilson, P. (2003). Faith-Based Organizations, Charitable Choice, and Government. Administration \& Society. 35(1); 29-51.

Xie, B., Davidson, W. N. and Dadalt, P. J. (2003). Earnings management and corporate governance: the role of the board and the audit committee. Journal of corporate finance, Vol. $9(3), 295-316$.

Zain, N. R. M. and Ali, E. R. A. E. (2017). An Analysis on Islamic Social Finance for Protection and Preservation of Maqāṣid Al-Sharī' ah. Journal of Islamic Finance, 176 (5872), 1-9.

Zuki, M.S.M.D. (2012). Waqf and Its Role in Socio-Economic Development, ISRA International Journal of Islamic Finance, Vol. 4(2). pp. 173-178. 
Zulfiqar, M. (2011). Zakah According to the Qur'an \& Sunnah, Riyadh, Kingdom of Saudi Arabia. 